\title{
F10 Gene
}

National Cancer Institute

\section{Source}

National Cancer Institute. F10 Gene. NCI Thesaurus. Code C76140.

This gene plays a role in proteolysis and blood clotting. 